\title{
Walter Benjamin: o Estado de Exceção entre o político e o estético ${ }^{1}$
}

\author{
Márcio Seligmann-Silva
}

Data de 1921 o famoso ensaio de Walter Benjamin "Zur Kritik der Gewalt", que, como muitos outros trabalhos do pensador berlinense, tinha um título intraduzível. Em português, visando dar conta da ambigüidade do termo Gewalt, encontramos uma tradução duplicadora: "Crítica da violência - Crítica do poder". A "indecidibilidade" que está no coração do termo alemão Gewalt, que significa tanto poder como violência (e afirma que um não existe sem o outro), já contém in nuce o centro da argumentação benjaminiana. Este texto de Benjamin nasceu a partir de uma reflexão sobre a situação política que a Europa vivia no pós-guerra, em meio a uma profunda crise das instituições políticas. Mas ele também desdobra determinados topoi de outros trabalhos seus, como a busca de uma esfera "pura" do relacionamento entre os homens (e deles com o mundo), bem como uma busca de "meios" independentes do serviço a determinados "fins". Reconhecemos também o uso de "teologemas", argumentos derivados do Antigo Testamento, que são aplicados à esfera do profano. Politicamente, Benjamin mais uma vez revela uma postura que o aproxima do anarquismo. Desta feita ele se vincula programaticamente a Georges Sorel e à sua teoria da greve geral revolucionária.

Neste texto, gostaria de, após apresentar as teses centrais do ensaio de 1921, retomar o percurso da leitura deste ensaio de Benjamin da parte de Carl Schmitt, bem como o diálogo entre estes dois intelectuais, tal como, entre outros, Horst Bredekamp e Giorgio Agamben o apontaram, para em seguida indicar como questões centrais do ensaio de 1921 são retomadas no livro sobre o Trauerspiel (Origem do drama barroco alemão $^{2}$ ) de 1925 e nos textos escritos no contexto do Passagen-Werk (Passagens), com destaque para o "Sobre o conceito da história", de 1940. A idéia é apresentar a figura da exceção, pensada tanto em termos políticos como no âmbito teórico-metodológico, como um conceito central que atravessa o pensamento de Benjamin. Aqui não pretendemos mais do que lançar esta hipótese e propor alguns meios de prová-la. A apresentação detalhada do ensaio sobre a Gewalt de 1921, em uma tentativa como que didática de 
close reading, é essencial para o que tento aqui. Para os que conhecem este texto de Benjamin em detalhes peço um pouco de paciência. A idéia é extrair do comentário do "teor material" deste texto algum pólen para a crítica.

\section{Crítica da Gewalt}

O ponto central do argumento de Benjamin em seu ensaio sobre a Gewalt é apresentado logo de saída em seu texto. "A tarefa de uma crítica da violência pode ser definida como a apresentação de suas relações com o direito [Recht] e a justiça [Gerechtigkeit]. Pois, qualquer que seja o efeito de uma determinada causa, ela só se transforma em violência, no sentido forte da palavra, quando interfere em relações éticas." $(160 ; 179)^{3}$ No campo do direito, Benjamin recorda, poderíamos criticar os meios em função dos fins, se justos ou não. Por outro lado, ele busca uma crítica mais radical, que permita refletir sobre a violência em si, ou seja, analisar se ela é ética mesmo servindo a fins justos. Para responder a esta questão, o autor propõe adotarmos provisoriamente o ponto de vista do direito natural, que "não vê problema nenhum no uso de meios violentos para fins justos". $(160 ; 180)$ Assim, o terrorismo justificaria o uso da violência em função de certos fins (considerados) justos. A violência é vista ai como algo natural. Como é conhecido, segundo esta teoria abrimos mão de nosso poder via um contrato social, por vermos no Estado um protetor. Benjamin estende esta teoria até o darwinismo social e sua defesa da violência como meio de cumprimento dos fins naturais. Aqui a violência aparece como meio adequado.

Oposta a esta perspectiva encontramos a tese do direito positivo (ou positivado), que ao invés de justificar os meios pelos fins, julga o direito pelos meios. "Se a justiça é o critério dos fins", escreve Benjamin, "a legitimidade é o critério dos meios." (161;180) Mas ambas as perspectivas ficam presas à idéia segundo a qual existe uma adequação entre meios e fins, já que meios justos devem gerar fins justos, estes são obtidos por aqueles. A lógica a que esta equação remonta reduz a justiça ora a legitimadora dos meios (no caso do direito natural), ora a algo garantido pelos meios legítimos (no caso do direito positivo). O passo seguinte de Benjamin consiste em deixar em suspenso a determinação da justiça e voltar-se para a questão da legitimidade dos meios. Neste ponto é importante 
lembrar a crítica benjaminiana da linguagem "decaída", apenas comunicativa e pensada como simples meio, que ele desenvolveu em mais de uma ocasião (lembremos aqui apenas de seu ensaio de 1916, "Sobre a linguagem em geral e sobre a linguagem dos homens", do ensaio sobre a tarefa do tradutor, de 1923, e do seu texto "Problemas da sociologia da linguagem", de 1935). Para pensar aquela legitimidade dos meios, Benjamin inicialmente aceita a tese do direito positivo, uma vez que este permite a distinção entre "sanktionierten und der nicht sanktionierten Gewalt" ("poder sancionado e o não-sancionado", 161; 181). A análise dos fins do poder não é suficiente para avaliá-lo: precisamos abordar o poder em sua origem histórica. Isto remete em Benjamin não apenas a uma "genealogia" (nietzschiana) das leis (dos mores), mas à sua "origem histórica" (162; 182).

Neste sentido ele se debruça sobre a cena política européia da sua época. Nela ele detecta uma antinomia entre a esfera jurídica, que quer integrar toda a sociedade em um sistema de fins jurídicos, e os fins naturais dos indivíduos. Estes não têm direito a recorrer à violência para concretizar seus fins. Por outro lado, o sistema jurídico, com seu monopólio da Gewalt/violência, parece querer apenas perpetuar a si mesmo. Neste ponto de sua argumentação Benjamin introduz pela primeira vez a figura do "'grande' bandido". Apesar de Benjamin não classificar deste modo, ele já representa uma aparição de um "estado de exceção" dentro da aparente normalidade do estado de direito. Para Benjamin, este "grande bandido" gera tanta admiração da parte do povo, justamente porque ele ostenta a violência/poder que lhes é proibido manifestar. O simples fato deste bandido ter acesso à violência é sentido como uma ameaça por parte da Gewalt/poder, independentemente de seus fins. A admiração do povo também não considera estes fins. $\mathrm{O}$ poder jurídico identifica neste desafio uma ameaça. E hoje sabemos até que ponto este sentir-se ameaçado (ou melhor, este apresentar-se como ameaçado) pode levar os detentores do poder a utilizar uma carga de violência inimaginável.

A segunda figura benjaminiana em seu texto de 1921, que nos remete à questão do "estado de exceção", surge quando ele discute os limites que o Estado-poder impõe ao direito de greve. Esta é aceitada como uma manifestação do operariado como sujeito jurídico que obteria uma permissão para exercer um poder limitado. Este poder é nãoviolento (nos termos de Benjamin: um meio puro), na media em que implica uma espécie 
de não-ação. Este poder é concedido aos trabalhadores para se evitar ações mais violentas. (168; 192) Mas se a greve assume as proporções de uma greve geral revolucionária, o Estado a classifica como abuso (Missbrauch, ou seja, como uma ameaça ao estado de direito) e apelará para decretos especiais, "Sonderverfügungen" $(163 ; 184)$. A greve geral revolucionária é vista como um uso inadequado do poder e direito atribuído aos trabalhadores. Benjamin fala do "caso limite", Ernstfall, deste tipo de greve que realiza uma passagem do uso legítimo de um direito, para a tentativa de se desestabilizar a própria ordem jurídica. Aqui o direito torna-se violência. Se o Estado responde com mais violência, isto não significa uma contradição ou o uso de uma simples "violência assaltante", raubende Gewalt, mas antes que a Gewalt, no caso da greve geral revolucionária, pode estabelecer novas relações jurídicas. Benjamin aprofunda esta tese a partir da análise da violência de guerra na sua dialética com o direito de guerra. Esta violência é caracterizada justamente como "violência assaltante". Ela revela que toda “paz”, não é nada mais do que uma sanção de uma vitória e o estabelecimento de uma nova ordem jurídica. ${ }^{4}$ Segundo o autor, é exatamente esta violência de guerra que deve servir de modelo para compreendermos qualquer violência. Da recente guerra européia, ele deduz que o militarismo revela uma dupla face da violência: enquanto uma compulsão (Zwang) para seu uso generalizado como meio para fins de Estado, ou seja, como meio para fins jurídicos, ela se revela tanto como "instituidora de direito" como também, por outro lado, como "mantenedora de direito". (165; 187) Deste modo Benjamin atinge o cerne da questão da Gewalt enquanto composição indissociável de violência e poder (jurídico). Sua crítica da Gewalt visa estas suas duas faces. Mesmo a máxima bem-intencionada de Kant, "aja de tal modo que você use a humanidade, tanto em nome da tua pessoa como na de qualquer outro, sempre como fim, nunca apenas como meio...", é vista como insuficiente e ingênua para se fazer uma crítica da Gewalt. Ela não é suficiente para dissociar o núcleo da Gewalt (além de afirmar uma "antropologia" limitada que parece desconhecer, eu acrescentaria, conceitos como o de trágico, o de sublime e o de medo, que marcam não só a história da Estética, mas sobretudo, explicitamente ao menos desde Maquiavel e Hobbes, a teoria política).

O direito positivo, nota ainda Benjamin, vê em cada indivíduo um representante do interesse da humanidade e de uma "ordem de destino". Esta submissão do indivíduo a 
esta ordem implica também a construção de um discurso que apenas reitera o status quo. A ordem do direito carece de um poder ameaçador ("Die rechterhaltende Gewalt ist eine drohende." 165; 188). Esta idéia nos faz lembrar de uma passagem da tragédia Eumênides de Ésquilo, quando a juíza, chefe do tribunal, Palas Atena, define a nova ordem jurídica que estava sendo instaurada a partir do julgamento de Orestes:

Prestai atenção ao que instauro aqui, atenienses, convocados por mim mesma para julgar pela primeira vez um homem, autor de um crime em que foi derramado sangue. A partir deste dia e para todo o sempre o povo que já teve como rei Egeu terá a incumbência de manter intactas as normas adotadas neste tribunal na colina de Ares [...] Sobre esta elevação digo que a Reverência e o Temor, seu irmão, seja durante o dia, seja de noite, evitarão que os cidadãos cometam crimes, a não ser que eles prefiram aniquilar as leis feitas para seu bem (quem poluir com lodo ou com eflúvios turvos as fontes claras, não terá onde beber). Nem opressão, nem anarquia: eis o lema que os cidadãos devem seguir e respeitar. Não lhes convém tampouco expulsar da cidade todo o Temor; se nada tiver a temer, que homem cumprirá aqui seus deveres? (E. 900-30 [681-99])

Esta aproximação com o universo mítico da tragédia que faço aqui corrobora para a interpretação de Benjamin da lei e da esfera do poder na sua relação com a do jurídico. Pois ele mesmo escreve: "A lei se mostra ameaçadora como o destino, do qual depende se o criminoso the sucumbe." O direito é visto como descendente do conceito de destino: neste sentido as punições revelam este aspecto mítico da lei. A crítica da pena de morte atingiria o poder na sua relação com a violência e o destino, a saber, atacaria o poder máximo que atua sobre o direito de vida e de morte. $\mathrm{O}$ direito se alimenta e se fortalece deste poder decisório sobre a vida e a morte. Aqui Benjamin detecta "um elemento de podridão dentro do direito" ("etwas Morsches im Recht", 166; 188).

A mesma ambigüidade da Gewalt que percebemos na punição via pena de morte é detectada em outra instituição estatal: a polícia. Esta ambigüidade deriva do fato dela ser ao mesmo tempo um órgão, melhor dizendo, uma Gewalt, do sistema jurídico e também estabelecer de certo modo seus próprios fins jurídicos por meio de decretos. Ela é, portanto, poder mantenedor e instituidor do direito. A polícia funciona como um instrumento do Estado que intervém onde o sistema jurídico esbarra no seu limite. Alegando "questões de segurança", o Estado pode assim controlar seus cidadãos. Benjamin fala de uma "vida regulamentada por decretos" (algo próximo do que veremos mais adiante, quando observarmos o que ele escreveu sobre a normalidade do Estado de 
Exceção). A polícia aparece como um poder gestaltlos, amorfo, em comparação com o direito que ainda fazia referência a uma "decisão", "Entscheidung" que valia como uma categoria metafísica que a abria à crítica. Neste sentido, Benjamin observa, não sem ironia, que o espírito policialesco, que parece ser tão compatível com a monarquia soberana, onde ele "representa o poder do soberano", reunindo suas funções legislativas e executivas, já nas democracias dá provas da "maior degenerescência imaginável do poder [Gewalt]". (167; 190) Esta idéia é essencial para destacar que todo poder também é meio do direito: seja para instituí-lo ou para mantê-lo. Não se pode criticar o poder sem se criticar o direito. Este recebe, a partir da reflexão sobre sua relação como que simbiótica com a Gewalt, uma luz ética ambígua.

Assim como Benjamin em seus textos sobre a linguagem procurava uma outra esfera, não comunicativa da mesma, aqui no texto de 1921 ele pergunta-se se não podemos encontrar uma esfera para a regulamentação de nossos interesses que pudesse dispensar este meio violento. Ele busca meios não-violentos, para além dos contratos jurídicos que sempre remetem a alguma violência. Visa uma esfera pura, independente também dos "compromissos" apenas aparentemente não violentos dos parlamentares da República de Weimar (e de tantas outras repúblicas). O parlamentarismo só pode existir dentro do seu compromisso com a Gewalt, conclui Benjamin. A questão, poderíamos acrescentar, é o que colocar em seu lugar: ou talvez trata-se de se imaginar e criar um lugar totalmente outro.

Os exemplos positivos de Benjamin neste ponto não são muito animadores. Ele encontra meios não-violentos, puros, na "cultura do coração" $(168 ; 191)$. Elogia a "atenção do coração, a simpatia, o amor pela paz". Outro exemplo, que poderia lembrar a ética dialógica da ação comunicativa de Habermas, é a conversa (Unterredung), onde impera, para Benjamin, a impunidade da mentira. Este conceito não deixa de lembrar a valorização da conversa pelo primeiro romantismo (lembremos do famoso texto de Friedrich Schlegel, Conversa sobre a poesia), que Benjamin conhecia tão bem, já que dois anos antes de escrever este texto defendera seu doutorado sobre o conceito de crítica daquele círculo de pensadores. $\mathrm{Na}$ linguagem e no entendimento que ela permite, Benjamin encontra este meio puro, não-violento. Daí também seu elogio da linguagem da diplomacia. (170; 195) Mas o exemplo central dele retoma a questão do direito de greve. 
A partir das Réflexions sur la violence de Georges Sorel, Benjamin estabelece uma distinção entre a greve geral política e a greve geral proletária. A primeira está totalmente comprometida com o poder enquanto sistema que se reproduz. No máximo ela pode levar à construção de uma nova ordem jurídica, que fatalmente reproduzirá a violência da ordem anterior. Neste caso, os privilegiados apenas trocam de nome. Já a greve geral proletária visa aniquilar o poder do Estado, visa superá-lo. Apenas esta greve, Benjamin propõe então, é verdadeiramente não-violenta, já que no seu horizonte não encontra-se a volta ao trabalho, mas sim a sua transformação absoluta. Esta greve anarquista não é violenta, apesar de suas "conseqüências catastróficas" $(170 ; 194)^{5}$, já que uma ação deve ser julgada em função de seus meios e não de suas conseqüências.

A conclusão de Benjamin deste balanço da relação da Gewalt com o direito condena o poder orientado seja segundo o direito natural, com seu culto dos fins e desprezo pela ética dos meios, seja segundo o direito positivo, que também é parte da lógica de sustentação do poder pelo meio jurídico, por mais que ele pareça legítimo. Assim como antes Benjamin se perguntara se existem meios não-violentos, ele busca neste passo outras modalidades de poder, para além das que a teoria do direito apresenta. Mas esta busca ocorre justamente por meio da crítica do direito. A indecibilidade que assombra o campo jurídico - "é impossível 'decidir' qualquer problema jurídico" (171; 196) - é apresentada com o exemplo lingüístico que afirma a impossibilidade de se decidir o que é "certo" e o que é "errado" em línguas vivas em transformação. Este exemplo é tanto mais importante, na medida em que aponta para a origem da aporia do sistema jurídico: ele depende da impossível adequação entre fins universais e situações particulares. Este sistema, poderíamos dizer, contém em si seu próprio o "estado de exceção". Como já se disse, todo ato de linguagem é em certa medida um "golpe de estado" com relação às regras da linguagem. Do mesmo modo o direito só existe dentro deste espaço (negado e temível) entre a lei e sua realização. Ele sempre depende, em última instância, do poder decisório dos que dominam o aparelho jurídico. Ele é sempre, portanto, poder instituinte e mantenedor.

Benjamin encontra uma função não mediativa da violência na ira, enquanto pura manifestação sem fim. A Gewalt mítica também assume este caráter de manifestação, como no caso, segundo o autor, da lenda de Níobe. A violência que desaba sobre ela teria 
a ver com o destino. Não é punição. Sua hybris - achar-se digna de honras divinas e mais feliz que Leto, mãe de Artemisa e Apolo - levou à morte de seus quatorze filhos. No mito Benjamin destaca justamente este enfrentamento do destino, sobretudo na figura de Prometeu, que encarnaria para ele a Gewalt jurídica. Prometeu se aproxima deste modo da figura do "grande bandido". Esta aproximação é importante, se levarmos em conta que este mito prometeico tem um status absolutamente fundamental e "fundante" na nossa cultura. Prometeu que traz a "luz" aos homens, as técnicas, o saber, o direito. Ele desafia o novo poder, instaurado e representado por Zeus, para criar uma nova linhagem de poder: humana. Na tragédia de Ésquilo, Zeus aparece como o lado violento do poder e Prometeu como suas face jurídica. A imagem do poder jurídico submetido à força instituidora de um novo poder soberano é paradigmática aí. Por outro lado, o próprio Benjamin estabelece uma ponte entre o poder imediato que se manifesta no mito e o poder instituinte do direito. "A institucionalização do direito é institucionalização do poder [Macht] e, nesse sentido, um ato de manifestação imediata da violência. A justiça é o princípio de toda instituição divina de fins, o poder (Macht) é o princípio de toda institucionalização mítica do direito.” (172; 198) Justiça e direito se excluem. Uma ligase, em Benjamin, ao divino, a outra ao mítico e à Gewalt.

Assim Benjamin retoma a discussão da instituição do tratado de paz para mostrar que os limites estabelecidos pelo tratado, de maneira “demoníaca e ambígua”, valem igualmente para os vencedores e os vencidos. Esta ambigüidade Benjamin denomina de mítica. Trata-se de uma ambigüidade perversa, na medida em que a proibição vale tanto para dominadores como para dominados, mas seu elemento coercitivo aplica-se, antes de mais nada, ao segundo grupo. Com Sorel ele recorda que todo o direito, Recht, é privilégio, Vorrecht, dos reis e dos eminentes, ou seja, dos poderosos, Mächtigen. (172; 198) E conclui: "E assim será, mutatis mutandis, enquanto existir o direito. Pois, da perspectiva da violência [Gewalt], a única a poder garantir o direito, não existe igualdade, mas, na melhor das hipóteses, existem poderes [Gewalten] do mesmo tamanho." (Id.) Mas a Gewalt em seu relacionamento com o sistema jurídico nunca abandona o espaço mítico. Pois, se a passagem da penitência (Sühne) para o castigo (Strafe) foi determinada pela passagem da lei oral para a escrita, por outro lado aquele que ignora esta é tratado pelo direito não como vítima do acaso (Zufall), mas sim do destino (Schicksal), com sua 
“ambigüidade proposital”. $(172 ; 199)$ Esta duplicidade está na origem de uma lógica de retro-alimentação do direito/poder que possui uma forma que recorda a circularidade (mítica). Afinal, as premonições míticas (e trágicas) sempre trazem em si a futura transgressão e o castigo. Com Hermann Cohen, Benjamin recorda que nestes casos “"é sua própria ordem que parece provocar sua transgressão, esse desrespeito.’” (Id.)

Desdobrando sua crítica, Benjamin deduz da identidade entre a Gewalt mítica e a do sistema jurídico a tarefa, Aufgabe, da sua aniquilação. Esta só pode se dar via oposição da Gewalt mítica por parte de uma outra, com um caráter inteiramente outro, que barre a simples reprodução desta força. Trata-se de encontrar uma Gewalt pura e imediata. Assim Benjamin opõe o poder mítico ao divino. Este último é o oposto do primeiro e permite aniquilar o direito. Aquele é rechtsetzende, instituidor de direito, este é rechtsvernichtende, aniquilador de direito, se um estabelece limites, o outro é semlimites, se um instaura a culpa e a penitência, o outro liberta da culpa, se um ameaça o outro resolve de um golpe, se um é sangrento, o outro é letal, mas não-sangrento. Nesta passagem, das mais controversas do ensaio de 1921, Benjamin confronta o mito de Níobe à lenda bíblica da destruição da corja de Corah (Números 16). Para ele, a aniquilação de um só golpe e não sangrenta realizada por Deus liberta da culpa. Este ser sem-sangue é central: pois "o sangue é símbolo da vida pura”, escreve Benjamin. A Gewalt mítica, por sua vez, remonta à culpabilização da vida pura natural que leva os inocentes à penitência e, no limite, destrói o próprio direito. Aquilo a que Benjamin denomina de "vida pura" indica também o limite do direito sobre os viventes. Aqui ressurge a diferença entre uma política dos meios e a dos fins puros: "O poder [Gewalt] mítico é poder [Gewalt] sangrento sobre a vida pura e por ela mesma, ao passo que o poder [Gewalt] divino o é sobre toda a vida tendo em vista os viventes." (173; 200, tradução modificada) O primeiro exige sacrificios, ou seja alimenta-se da vida pura, destruindo-a, o segundo, escreve Benjamin (de modo enigmático) simplesmente aceita estes sacrifícios. O poder divino é puro.

O penúltimo passo do ensaio benjaminiano desdobra esta reflexão sobre a relação entre poder/direito mítico e o sacrifício da vida pura e, por outro lado, o poder divino como golpeador e não-jurídico. Se este último poderia dar a entender que a capacidade letal poderia ser estendida aos homens, isto não ocorre pois o mandamento "Não 
matarás" impede a realização do ato. No entanto, este mandamento não deve estar nem na origem da contenção diante do ato, nem do seu eventual julgamento. Este ponto é essencial para se demarcar a esfera do direito mítico e a do poder divino. "O mandamento não existe como medida de julgamento, e sim como diretriz". (173; 200) E, mais ainda, não se deve deduzir dele a tese errônea do caráter sagrado da vida, seja ela vegetal, animal ou humana. ${ }^{6}$ Para Benjamin é falso que a existência estaria acima da existência justa, na medida em que existir signifique apenas a "vida pura". Mas "vida", para este autor, assim como a palavra "paz" que vimos acima, deve ser considerada como uma linha entre duas esferas, o que a torna eminentemente ambígua. Se considerarmos o existir como o estado agregado inabalável da "pessoa", podemos aceitar que o não-ser desta possa ser mais terrível que o mero ainda não-ser da pessoa justa. Mas não se trata de sacralizar a vida, o corpo humano, Leib, em função do elemento sagrado da pessoa. $\mathrm{O}$ autor se pergunta sobre a diferença entre as pessoas e os animais e plantas, para afirmar que estes últimos não teriam um caráter sagrado devido à pura vida. O programa de pesquisa que ele propõe então foi seguido à risca por Agamben: "Sem dúvida, valeria a pena investigar o dogma do caráter sagrado da vida.” (174; 202) Para Benjamin, este dogma deve ser recente e considerado um equivoco da tradição ocidental enfraquecida, que busca o sagrado perdido no impenetrável cosmológico. Ele arremata seu raciocínio com um teorema (como que kafkiano): ele se espanta diante do fato de que se atribua o caráter de sagrado justamente à vida pura, ou seja, àquilo que o pensamento mítico considera como o que porta a culpa. Assim ele fecha o círculo de seu estudo: o poderdireito mítico exige o sacrifício da vida sacra. Apenas a crítica da Gewalt pode nos instrumentalizar contra este círculo onde a lei, o sagrado e a culpa se alimentam eternamente.

Esta crítica não é apresentada como genealogia, mas sim como uma "fillosofia" da sua história. A mise en perspective derivada deste ponto de vista traça um ponto arquimediano fora da esfera do poder-violência que permite este olhar crítico. Assim, Benjamin propõe, no seu último passo, a possibilidade de ruptura na cadeia de embates históricos e míticos entre poderes mantenedores e poderes instituintes. A nova era histórica é anunciada, como aquela sem um poder do Estado. O poder puro, revolucionário e humano que Benjamin evoca, é posto em paralelo com o poder divino, 
que dispõe daquilo que o mito reduziu ao direito. Mas novamente Benjamin é infeliz na escolha de seus exemplos de tal poder puro: ele o vê tanto na "verdadeira guerra" como no "juízo divino da multidão sobre o criminoso". Em contrapondo ao "poder que o homem põe", schaltende Gewalt, que não abandona o mito e depende do direito, assim como ao poder mantenedor, administrado, verwaltete Gewalt, ele propõe o poder divino, que nunca é meio e pode ser chamado de "poder que dispõe", waltende Gewalt. Se recordarmos que em alemão se diz "schalten und walten", no sentido de "pôr e dispor", mandar, e das expressões walt's Gott, em nome de Deus!, ou das walte Gott, assim seja!, podemos compreender melhor este jogo de palavras de Benjamin com o termo Gewalt. Em português dizemos também que "o homem põe e Deus dispõe". Aqui se trata de uma equação simples: o direito instituído, humano, é ligado ao que mantém o status quo e ambos são contrapostos ao poder divino que dispõe segundo a sua vontade.

\section{Benjamin leitor de Carl Schmitt e vice-versa}

A história da recepção mais intensa deste ensaio de Benjamin de 1921 normalmente é contada apenas a partir do famoso texto de Derrida Force de loi, publicado em 1994 e escrito no final dos anos 1980 e início da década seguinte. Mas na verdade esta recepção deu-se de modo imediato, já que Carl Schmitt deve ser contado como um dos leitores de primeira hora do ensaio de Benjamin. Este por sua vez, reconheceria no livro de Schmitt Politische Theologie uma série de idéias que lhe ajudaram na construção de seu ensaio sobre o drama barroco alemão. É justamente esta proximidade de interesses entre Benjamin e Schmitt que está na origem da crítica avassaladora que Derrida fez a este texto (Derrida 1994: 69). Crítica que me parece injusta e precipitada. Talvez apenas uma espécie de "pequena" tentativa, da parte de Derrida, de matar o "pai”, ou um de seus pais intelectuais.

Mas é verdade que Carl Schmitt foi não só um eminente membro do partido nazista, como existem várias passagens anti-semitas em sua obra. Ele foi o autor de textos como "Der Führer schützt das Recht” (“O Führer protege o direito", 1934) e "Die deutsche Rechtswissenschaft im Kampf gegen den jüdischen Geist” (“A ciência jurídica alemã em luta contra o espírito judaico", 1936). (Weber: 5) O ensaio de Derrida, assim 
como o de Benjamin, parte da aporia jurídica, ou seja, de sua relação estrutural com a violência. Derrida escreve sobre a relação entre a lei e sua aplicabilidade, enforceability, que depende da "força". (1994: 18) Se o direito pode ser desconstruído, como Benjamin o demonstrou, a justiça não o pode ser. (1994: 35) Partindo do ensaio de Benjamin, Derrida também analisa a relação entre direito e sacrifício (1994: 43); com Lévinas, ele escreve sobre a relação dialógica com o outro como possível fundamento de uma justiça (1994: 48s.), entre outros temas que não caberia recordar aqui. O importante é que a partir de uma grande identificação de temas da desconstrução com o texto (e a obra) de Benjamin, Derrida parte, na segunda metade de seu ensaio, para um ataque a "este texto inquietante, enigmático, terrivelmente equivocado, [...] assombrado pelo tema da destruição radical, da exterminação, da aniquilação total [...]" (1994: 67). Derrida interpreta a idéia de justiça divina, violenta, de um golpe e não-sangrenta, como uma espécie de assombração do extermínio judaico que pairaria sobre o ensaio benjaminiano. Mas não é só de uma assombração e de uma premonição que se trata. Para Derrida é como se Benjamin estivesse não apenas prevendo, mas justificando as câmaras de gás. (1994: 71, 145) Falar de uma cumplicidade entre o ensaio de Benjamin e a "solução final" é de um teleologismo absurdo que parece-me "inquietante, enigmático, terrivelmente equivocado". Se Derrida tem toda a razão em constatar certas proximidades (perigosas) entre Benjamin e algumas passagens de Schmitt e Heidegger, entre, por exemplo, a hostilidade deles ao parlamentarismo democrático, daí a deduzir esta interpretação do texto de 1921, parece-me precipitado. ${ }^{7}$ Mas com isso não quero negar a necessidade de desconstrução do texto benjaminiano. Quando Derrida afirma que a polaridade entre greve geral política e proletária deve ser desconstruída, é difícil não concordar (1994: 93); tampouco pode-se negar o elemento enigmático e, hoje, pouco produtivo, da idéia de violência divina, assim como os traços conservadores da crítica benjaminiana da degenerescência (Entartung, 175; 202) do poder e da decadência (Verfall, 167; 190) das instituições jurídicas. (Derrida 1994: 111s.) Não é de admirar que Derrida tenha se sentido um tanto chocado com estes conceitos. Mas isto não justifica seu teleologismo.

Mas o que importa aqui não são os detalhes desta leitura derridiana do "Zur Kritikder Gewalt" (um tema muito importante para um estudo da obra do próprio Derrida), mas sim a teoria do "estado de exceção" de Benjamin e como esta pode ser 
melhor compreendida se levarmos em conta este diálogo com Carl Schmitt. A relação entre Benjamin e Schmitt está documentada em poucas passagens. Além da citação do livro Politische Theologie no seu ensaio sobre o drama barroco alemão que logo veremos, devemos lembrar de uma carta a Richard Weissbach de 23.03.1923, da carta que Benjamin enviou a C. Schmitt em 9.12.1930, onde avisa que ele em breve receberá seu ensaio sobre o Trauerspiel, e de uma passagem de um curriculum vitae de 1928.

$\mathrm{Na}$ carta a Weissbach, Benjamin escreve: "Quando da minha última visita eu esqueci o Politische Theologie do Schmitt com o senhor. O senhor poderia, por favor, gentilmente enviá-lo a mim. Ele é importante para o meu trabalho atual sobre o Trauerspiel." "Já o curriculum de 1928 revela pistas preciosas para a compreensão da obra de Benjamin daquele período:

Assim como Benedetto Croce com a destruição da doutrina das formas artísticas [Kunstformen] abriu o caminho para a obra única concreta, assim os meus ensaios até agora têm se esforçado em abrir o caminho para a obra de arte através da destruição da doutrina do caráter disciplinar da arte. Seu objetivo programático comum é o processo de integração da ciência que mais e mais deita ao chão as paredes divisórias entre as disciplinas, tal como o conceito de ciência do século passado as caracterizavam, com base no fomento de uma análise da obra de arte que reconheça nela uma expressão integral, sem delimitar em um campo restrito, das tendências religiosas, metafísicas, políticas e econômicas de uma época. Este ensaio, que eu levei a cabo em uma escala ampla no mencionado Origem do drama barroco alemão, conecta-se, por um lado, com as idéias de Alois Riegl e sua doutrina do Kunstwollen, por outro lado, com as tentativas atuais de Carl Schmitt, que realiza na sua análise das configurações políticas uma tentativa análoga de integração dos fenômenos, que apenas na aparência são separados segundo os campos. Sobretudo, no entanto, uma tal observação parece-me condição para toda compreensão fisionômica profunda da obra de arte no ponto em que elas são incomparáveis e únicas. Neste sentido, ela se aproxima mais da observação eidética dos fenômenos do que da sua observação histórica. (GS VI, pp.218s.)

Benjamin buscava tanto modelos capazes de superar as compartimentações entre as disciplinas, como também reconheceu na obra de Schmitt um método para salvar o elemento único, incomparável, das obras. Aqui encontramos, portanto, um tema central de sua introdução ao livro sobre o Trauerspiel.

A carta a Schmitt é formal e indica o desejo de continuar um diálogo intelectual com o então eminente teórico do direito, crítico literário e escritor surrealista. Como se 
trata da única carta de Benjamin a Schmitt de que temos conhecimento e, por outro lado, como encontramos nela algumas afirmações reveladoras, também vale a pena citá-la ${ }^{9}$ :

\section{Prezado Professor,}

Por estes dias o senhor receberá da editora o meu livro Ursprung des deutschen Trauerspiels [Origem do drama barroco alemão]. Com estas linhas eu gostaria não apenas de anunciá-lo, mas também de expressar-lhe minha alegria quanto ao fato de que pude enviá-lo graças ao senhor Albert Salomon. O senhor irá notar muito rapidamente quanto o livro deve a sua apresentação da doutrina da soberania no século XVII [Cf. Politische Theologie, 1922]. Talvez eu deva, além disso, já dizer que derivei de suas obras posteriores, particularmente de Diktatur, uma confirmação dos meus métodos de pesquisa em filosofia da arte das suas sobre filosofia do estado. Se a sua leitura do meu livro tornar compreensível este sentimento, o propósito do meu envio terá se cumprido.

Com a expressão de uma particular admiração,

Atenciosamente,

Walter Benjamin (Benjamin 1997: 558)

Novamente Benjamin destaca este encontro metodológico entre sua obra e a do teórico do direito. Por outro lado, como vimos, não podemos perder de vista que o próprio Schmitt foi um leitor de Benjamin. Está praticamente provada a sua leitura do ensaio de Benjamin sobre a Gewalt de 1921, publicado no Archiv für Sozialwissenschaft und Sozialpolitik (número 47 de 1920-21), revista da qual Schmitt era leitor habitual, como apontou G. Agamben. (2004: 84) Além disso, no pós-guerra Schmitt voltou a lidar de modo intenso com a obra de Benjamin a partir de sua discussão da tragédia em seu livro Hamlet oder Hecuba. Die Einbruch der Zeit in das Spiel (Hamlet ou Écuba. A irrupção do tempo no drama), de 1956. Como recorda Horst Bredekamp, Carl Schmitt escreve em uma série de cartas de 1973, que durante os anos 1930 ele se ocupou de Benjamin. A apresentação deste relacionamento ultrapassa a troca intelectual. Schmitt enfatizou que tinha contatos diários com amigos em comum dele e de Benjamin. Estes contatos não estariam documentados por escrito justamente porque eram cotidianos e pessoais. Schmitt apresenta também seu estudo sobre o Leviathan e Hobbes de 1938 como uma resposta ao livro de Benjamin sobre o drama barroco e à sua incapacidade de lidar com este tema da filosofia política. Bredekamp também parece ter razão ao apontar esta reconstrução autobiográfica de Schmitt nos anos 1970 como uma tentativa de se libertar 
da culpa de seu passado nazista via esta aproximação com o então já amplamente reconhecido intelectual de esquerda, "entronizado" por 1968, que era Benjamin. Independentemente desta política da memória, no entanto, ele considera que faz muito sentido pensar no estudo schmittiano da figura do Leviathan como uma resposta ao ensaio de Benjamin. Contra a tese benjaminiana do período barroco como uma era instável e imprópria para a autoridade absoluta do soberano (que se aproximaria do conceito hobbesiano de estado de natureza) Schmitt mostra que havia sim espaço para aquela figura do poder centralizado. (Bredekamp 1999: 261s.)

É importante destacar, portanto, que neste diálogo intelectual predomina uma admiração distanciada. Apesar da aproximação possível entre determinados pontos de vista políticos (a crítica ao parlamentarismo e ao liberalismo de então), apesar da atração pela teoria da soberania no século XVII e da paixão metodológica pelo estudo dos fenômenos extremos, a leitura recíproca sempre valeu como inspiração, mas também como tomada de distanciamento crítico. Normalmente um autor revertia o teorema lido no outro: isto se passa tanto na questão da teoria da soberania como na do estado de exceção. A famosa definição schmittiana da soberania, "Souverän ist, wer über den Ausnahmezustand entscheidet"10 ("Soberano é aquele que decide sobre o estado de exceção"; Schmitt 1996: 13), pode refletir em parte as idéias do ensaio de Benjamin sobre a violência, mas não corresponderá à própria descrição benjaminiana da figura do soberano no século XVII. A este conceito de soberania corresponde ainda, em Schmitt, a idéia de decreto de urgência, Notverordnung ou de estado de sítio, Belagerungzustand. Estes conceitos da teoria política reaparecem em termos de uma reflexão epistemológica e de filosofia da história. Assim, a idéia contida na frase seguinte de Schmitt, após esta definição de soberania em Politische Theologie, também reaparece no livro sobre o Trauerspiel, desta feita sem a reversão. Aqui trata-se justamente de um preceito teóricometodológico e não de um teorema político. Citemos Schmitt: "Diese Definition kann dem Begriff der Souveränität als einem Grenzbegriff allein gerecht werden.” (“Apenas esta definição será compatível com o conceito de soberania enquanto um conceitolimite." 1996: 13) Também Benjamin considerará seu conceito de Trauerspiel um conceito-limite. Segundo ele, apenas nestas aparições extremas pode-se determinar os conceitos da teoria estética. 
Por sua vez, Carl Schmitt, no seu ensaio sobre o Hamlet ao invés de fazer uma teoria da origem como Ursprung, ou seja, como uma espécie de fenômeno que rompe com a linearidade do histórico, onde a pré- e pós-história do conceito estudado se encontram, como Benjamin propusera na famosa introdução crítico-epistemológica de seu ensaio sobre o barroco, propõe a noção quase que oposta de Einbruch, ou seja, de irrupção do elemento histórico na obra trágica. Neste brilhante ensaio - sem dúvida uma das teorias mais fortes do drama e do trágico da segunda metade do século $\mathrm{XX}$ - ele critica tanto a leitura que Benjamin faz de Hamlet (Schmitt descarta a sua cristianização de Shakespeare) como a sua análise do conceito de soberania (que não teria levado em conta as diferenças entre o continente europeu e a situação insular da Inglaterra). (Schmitt 1993: 53) Mas, por outro lado, também é verdade que Schmitt se apóia amplamente em Benjamin e no seu livro sobre o Trauerspiel. Se levarmos em conta que em Benjamin também encontramos uma forte teoria da literatura e das artes como testemunho de sua época, fica claro que a diferença entre estes dois autores derivada a partir dos conceitos benjaminiano de origem e schmittiano de irrupção, é mais superficial do que decisiva. Tentemos apontar de modo mais detalhado alguns momentos do diálogo entre Schmitt e Benjamin, enfatizando a obra deste último e sem perder de vista a centralidade da questão do estado de exceção nestes dois autores.

\section{O ensaio sobre o Trauerspiel}

Antes de apresentarmos a questão da exceção no livro de Benjamin sobre o barroco, vale a pena recordar a resposta schmittiana à teoria da Gewalt pura de Benjamin. Neste ponto as análises de Agamben são preciosas. Este autor vê o ensaio Politische Theologie como uma "resposta precisa" ao texto benjaminiano "Zur Kritik der Gewalt". (2004: 85) Citemos as suas palavras: “Enquanto a estratégia da 'Crítica da violência' [sic] visava a assegurar a existência de uma violência pura e anômica, para Schmitt trata-se, ao

contrário, de trazer tal violência para um contexto jurídico. O estado de exceção é o espaço em que ele procura capturar a idéia benjaminiana de uma violência pura e inscrever a anomia no corpo mesmo do nomos." (2004: 85s.) Segundo Agamben, o que está em jogo na resposta de Schmitt é a idéia de uma violência pura fora da esfera do 
direito: isto não pode existir para ele, pois o estado de exceção justamente inclui a violência no direito no mesmo momento em que suspende este. A noção de decisão de Schmitt também supera a polaridade entre poder constituinte e constituído. O poder soberano em Schmitt está além desta polaridade, ele simplesmente suspende o direito. Também a indecidibilidade das questões jurídicas, afirma Agamben, é superada por Schmitt em Politische Theologie, graças à figura do soberano como quem é capaz de decisão. É esta decisão que permite se estabelecer uma ponte entre a anomia e o sistema jurídico. (Id.) Visto isto, passemos à resposta benjaminiana ao Politische Theologie.

Benjamin, no item de seu livro de 1925 sobre o Trauerspiel dedicada à "Teoria da soberania", recorre ao Politische Theologie para apresentar a nova ordem política do século XVII. "O conceito moderno de soberania tende para um poder executivo assumido pelo príncipe, o Barroco desenvolveu-se a partir da discussão do estado de exceção [Ausnahmezustand], considerando que a mais importante função do príncipe é impedi-lo. Aquele que exerce o poder está predestinado de antemão a ser detentor de um poder ditatorial em situações de exceção provocadas por guerras, revoltas ou outras catástrofes." (Benjamin 2004: 57s., correspondendo a GS I, pp.245s.) Mais importante no nosso contexto, é a explicação filosófico-histórica de Benjamin para este estado político excepcional:

O barroco contrapõe frontalmente ao ideal histórico da Restauração a idéia de catástrofe. E a teoria do estado de exceção constrói-se sobre esta antítese. Por isso, não basta invocar a maior estabilidade das condições políticas do século XVIII para se explicar de que modo se perde neste século 'a consciência da importância do estado de exceção, dominante no direito natural do século XVII'. [C. Schmitt] [...] O homem religioso do Barroco prende-se tão fortemente ao mundo porque sente que com ele é arrastado para uma queda de água. Existe uma escatologia barroca ${ }^{11}$; por isso o que existe é um mecanismo que acumula e exalta tudo o que é terreno antes de entregar à morte. $\mathrm{O}$ além é esvaziado de tudo aquilo que possa conter o mínimo sopro mundano, e o Barroco extrai dele uma panóplia de coisas que até aí se furtavam a qualquer configuração artística, trazendo-as, na fase do seu apogeu, violentamente à luz do dia para esvaziar um derradeiro céu que, nessa sua vacuidade, será capaz de um dia destruir a terra com a violência de uma catástrofe. (Benjamin 2004: 58s.; correspondendo a GS I, p.246. Tradução modificada)

Ou seja, ao invés de uma teoria do soberano e de sua legitimação via estado de exceção, Benjamin dá a esta situação excepcional uma dimensão tão radical que destrói o reino 
sobre o qual este soberano poderia reinar. Impera não o soberano, mas sim a catástrofe. Melhor dizendo, as catástrofes do presente que serão triunfalmente finalizadas com uma catástrofe futura. (Cf. Seligmann-Silva 2003) O que resta aos viventes nesta situação sem redenção de anomia é o jogo-lutuoso (literalmente: Trauer-spiel) com as ruínas do mundo. Daí a centralidade, neste ensaio de Benjamin, dos conceitos de melancolia e de alegoria. O alegorista é o colecionador de escombros, que, resignificando-os, salva-os. Em outro item do mesmo capítulo sobre o "Drama Trágico [Trauerspiel] e a Tragédia", Benjamin destaca a "Incapacidade de decisão" do soberano. Nada menos caro à teoria da soberania de Schmitt: "A antítese entre o poder do soberano e a sua efetiva capacidade de governar levou, no drama trágico, a uma característica muito própria, que só aparentemente é um traço de gênero, e que só pode ser explicada à luz da teoria da soberania. Trata-se da incapacidade de decisão do tirano. O príncipe, cuja pessoa é depositária da decisão do estado de exceção, demonstra logo na primeira oportunidade que é incapaz de tomar uma decisão.” (2004: 66; correspondendo a GS I, p. 250). Benjamin nota que existe por detrás do drama de tirano barroco elementos da tragédia de mártires. O soberano barroco, para ele, oscila entre a figura do tirano e a do mártir. Benjamin nota que, por outro lado, também nas histórias de mártires do Barroco pode-se perceber o drama do tirano. O monarca é aquele que passa por uma prova, assim como o mártir. "A função do tirano é a restauração da ordem na situação de exceção: uma ditadura cuja utopia será sempre a de colocar as leis férreas da natureza no lugar do instável acontecer histórico. Mas também a técnica estóica visa um objetivo parecido: controlar, com o domínio dos afetos, o que pode ser visto como estado de exceção da alma [Ausnahmezustand der Seele]." (Benjamin 2004: 68; correspondendo a GS I, p.253). Aqui Benjamin transpõe um fenômeno descoberto no campo da teoria política para o campo da teoria do pathos do drama barroco. De tirano a indeciso, de ditador a soberano em luta com suas paixões sob um céu não-transcendente, nestas transposições dos conceitos de Schmitt, Benjamin atribui cores totalmente distintas e próprias à sua teoria do estado de exceção.

Por outro lado, em termos epistemológicos assim como em termos de uma atração por uma temporalidade "de exceção", podemos sim detectar continuidades flagrantes entre estes dois pensadores. Na sua teoria das idéias apresentada na introdução do livro 
sobre o drama barroco, Benjamin afirma que as idéias devem ser atingidas pela contemplação dos fenômenos únicos. Nelas, estes fenômenos são reunidos e são salvos. Entre o fenômeno e a idéia, Benjamin descreve o trabalho dos conceitos: "aqueles elementos, que os conceitos têm por tarefa destacar dos fenômenos, são mais claramente visíveis nos extremos da constelação. A idéia é definível como a configuração daquele nexo em que o único e extremo se encontra com o que lhe é semelhante. [...] O universal é a idéia. Já o empírico será tanto mais profundamente apreendido quanto mais claramente for visto como algo extremo. O conceito procede de algo extremo." (2004: 21; correspondendo a GS I, p.215). Portanto, os conceitos poetológicos não devem ser pensados como "médias" ou sumas dos fenômenos. Benjamin trata o Trauerspiel como uma idéia. Isto o opõe à tradição da composição da história das idéias. Ele valoriza uma aparição marginal nestas histórias, o drama barroco alemão. É aí que Benjamin encontra toda a carga explosiva do Trauerspiel. Nestas aparições extremas pode-se, para ele, perceber melhor os traços do gênero, do que nas suas manifestações mais perfeitas, como pôde-se ver na Inglaterra e sobretudo na Espanha. ${ }^{12}$

Benjamin visa a uma "verdadeira contemplação", como vimos, ele quer salvar as obras na sua concretude e singularidade, sem abandonar a noção de idéia e rejeitando o método dedutivo. Daí o seu conceito de origem, como algo oposto à noção de gênese, Entstehung. "Origem não designa o processo de devir de algo que se originou [Entsprungenen], mas antes aquilo que emerge [Entspringende] do processo de devir e desaparecer. A origem insere-se no fluxo do devir como um redemoinho que arrasta no seu movimento o material produzido no processo de gênese [Entstehungsmaterial]." (2004: 32; correspondendo a GS I, p.226. Tradução modificada.). Este "emergir" é justamente uma metáfora do procedimento benjaminiano de romper com o modo de pensar linear e ascendente tradicional. Trata-se da idéia de Ursprung, como salto, Sprung, para fora desta linearidade, destruindo os falsos nexos e contextos. Assim Benjamin pretendia não abandonar o histórico, mas sim salvá-lo do único modo que lhe parecia possível, sem ocultar suas rupturas e tensões.

"Sobre o conceito da história", choque e reprodutibilidade como rupturas na tradição 
Do mesmo modo que no barroco Benjamin detectou um visão da história como um contínuo de catástrofes, nas suas reflexões históricas dos anos 1930 esta idéia tornouse cada vez mais central. Agora tratava-se não mais de um estudo do século XVII (por mais que Benjamin tenha deixado claro que estudou o barroco visando compreender e iluminar seu presente), mas sim da análise de uma situação concreta: a Alemanha nazista existiu por seus doze anos sob o signo de um estado de exceção declarado. As reflexões contidas no seu último texto, o "Sobre o conceito da história", em parte reúnem idéias que já haviam sido avançadas ao longo da década anterior pelo próprio Benjamin. A teoria do choque, que ele desenvolveu a partir de suas leituras de Freud, de Baudelaire, de Poe, entre outras figuras-chave, também indica a presença desta modalidade do tempo que irrompe para estancar a continuidade da vida "normal". O conhecido poema de Baudelaire sobre a perda da aureola apenas indica uma das modalidades do choque que penetrou a vida moderna e impede, para Benjamin, a construção da Erfahrung, experiência autêntica, capaz de articular a tradição e o passado ao presente. Já a teoria da reprodutibilidade técnica e a teoria da passagem para o registro pós-aurático no campo das artes também devem ser lidas no seu momento de filosofia da história, na medida em que Benjamin fala no seu artigo de 1936 de um "abalo violento da tradição" causado por esta reprodutibilidade. (Cf. Seligmann-Silva 2005) Benjamin deduz do estado de onipresença dos choques na sociedade moderna a necessidade de um método de pesquisa e de um trabalho de Darstellung, apresentação, desta pesquisa, condizentes com esta nova realidade. Este é, de certo modo, o seu "salto tigrino" no céu da teoria. Daí a centralidade do conceito de "montagem" no seu trabalho sobre as passagens de Paris. O tempo-do-agora, que marca sua nova teoria da escritura histórica, é o que resta ao homem submetido à fragmentação da tradição. Benjamin desenvolveu um método de trabalho à altura da humanidade na era do estado de exceção. Justamente as reflexões epistemológicas contidas nas fichas do Trabalho das passagens também indicam um aprofundamento tanto do método benjaminiano de trabalhar com os extremos, como de seu projeto de se manter próximo aos fenômenos e não dissolvê-los na média ou mediocridade dos conceitos tradicionais. O conceito de colecionador que ele desenvolveu 
então, desdobra a noção de alegorista, do livro sobre o Trauerspiel, como aquele que, como vimos, recolhe e salva as ruínas do histórico.

Para finalizar esta apresentação da questão do estado de exceção em Benjamin, não podemos deixar e citar algumas das suas teses de 1940. Aqui ele levou às últimas conseqüências tanto o seu método como a sua concepção da história. Na sexta tese lemos com relação ao procedimento do historiador: "Articular o passado historicamente não significa reconhecê-lo 'como ele de fato aconteceu'. Significa apropriar-se de uma recordação como ela relampeja no momento do perigo.” (GS I, p.695) Benjamin exige do historiador presença de espírito para este ato tanto epistemológico como político. $\mathrm{O}$ "momento do reconhecimento" de que a tese cinco fala, é o momento do conhecimento no qual devemos conseguir reconhecer uma imagem do passado que passa diante de nós rapidamente. ${ }^{13}$ Ao estado de exceção onipresente corresponde uma ação excepcional visando à libertação. O historicismo correspondia a uma visão da história etapista e progressista: seu adepto era o burguês satisfeito com o trajeto histórico. Benjamin apresenta o ponto de vista não propriamente oposto, mas totalmente outro, já que explode com aquela estrutura de pensamento.

Para tanto, ele utiliza novamente uma metaforologia teológica. Revolucionar muitas vezes pode significar resgatar o "passado". Este é sempre o caso em Walter Benjamin. Ele fala na tese seis de um Messias que vem não como salvador, mas sim como vencedor do Anticristo. Novamente poderíamos pensar em Schmitt e em sua teoria (maniqueísta) do político como um estado de luta entre inimigos. Como Jacob Taubes destacou: "Na luta contra o Historismo Carl Schmitt concordava com Walter Benjamin, ou, mais exatamente: Walter Benjamin concordava com Carl Schmitt." (Taubes 1987: 26) ${ }^{14}$ Mas é na oitava tese, que o conceito de estado de exceção aparece com todo o seu significado:

A tradição dos oprimidos nos ensina que o 'Estado de Exceção', no qual nós vivemos, é a regra. Precisamos atingir um conceito de história que corresponda a isto. Então teremos diante de nós como nossa tarefa provocar o efetivo Estado de Exceção; e deste modo melhorará a nossa posição na luta contra o fascismo. A sorte deste depende não em última instância, que seus opositores lutem contra ele em nome do progresso como uma norma histórica. - A admiração de que as coisas que nós vivenciamos 'ainda' são possíveis no século XX, não é fillosófica. Ela não está no início de um conhecimento, a não ser de que a idéia de história, de onde ela provém, não pode mais ser sustentada. (GS I, p.697) 
Já a famosa tese nove sobre o anjo da história, apresenta novamente o histórico como um inesgotável acumular de destroços de uma mesma e eterna catástrofe-tempestade a que denominamos "progresso". Podemos imaginar o anjo desta tese como o Deus detentor da violência pura do ensaio de 1921. Mas este Deus está agora impotente: não pode intervir no processo histórico, estancá-lo e colher os destroços. Ao estado de exceção como norma, Benjamin opõe uma sociedade inteiramente outra, assim como no ensaio de 1921 ele tinha em vista uma sociedade livre do poder mítico da esfera jurídica. Olhando suas idéias hoje, mais de meio século depois, só podemos constatar consternados o quanto ele estava certo em sua descrição da nossa sociedade - e também em seus sonhos de libertação.

Obras citadas:

AGAMBEN, Giorgio. Estado de exceção, trad. I. Poleti, São Paulo: Boitempo, 2004. (tradução de Stato de eccezione, Bollati Boringhieri, 2003)

BENJAMIN, Walter. "Zur Kritik der Gewalt", in: Gesammelte Schriften, org. por R. Tiedemann und H. Schweppenhäuser, Frankfurt a.M.: Suhrkamp, vol. II: Aufsätze, Essays, Vorträge, 1974. Pp. 179-203.

BENJAMIN, Walter. "Crítica da Violência. Crítica do Poder", trad. de Willi Bolle, in: W. Benjamin, Documentos de Cultura, Documentos de Barbárie, org. W. Bolle, S. Paulo: Cultrix/EDUSP, 1986, pp. 160-175.

BENJAMIN, Walter. Gesammelte Briefe. Band II. 1919-1924, org. por Ch. Gödde e H. Lonitz, Frankfurt a.M.: Suhrkamp, 1996.

BENJAMIN, Walter. Gesammelte Briefe. Band III. 1925-1930, org. por Ch. Gödde e H. Lonitz, Frankfurt a.M.: Suhrkamp, 1997.

BENJAMIN, Walter. Origem do drama trágico alemão, trad. João Barrento, Lisboa: Assírio Alvim, 2004.

BENJAMIN, Walter. Passagens. Org. Willi Bolle; colaboração na organização Olgária Chain Féres Matos; tradução do alemão Irene Aron; tradução do francês Cleonice Paes Barreto Mourão. Belo Horizonte: Editora UFMG; São Paulo: Imprensa Oficial do Estado de São Paulo, 2006.

BREDEKAMP, Horst, "From Walter Benjamin to Carl Schmitt, via Thomas Hobbes", in: Critical Inquiry, vol. 25, n. 2, Winter 1999, pp. 247-66.

DERRIDA, Jacques. Force de Loi. Le "Fondement mystique de l'autorité", Paris: Galilée, 1994.

ÉSQUILO. Oréstia. Agamêmnon, Coéforas, Eumênides, trad. Mário da Gama Kury, Rio de Janeiro: Jorge Zahar, 6a. ed., 2003. 
NIETZSCHE, F. Jenseits von Gut und Böse, Zur Genealogie der Moral. Eine Streitschrift, in: Kritische Studienausgabe, org. G. Colli e M. Montinari, München: DTV/ Berlin-New York: Walter de Gruyter, vol. 5, 1988.

NIETZSCHE, F. Genealogia da Moral. Uma polêmica, trad. Paulo C. Souza, S. Paulo: Companhia das Letras, 1998.

SCHMITT, Carl. Politische Theologie. Vier Kapitel zur Lehre von der Souveränität, München, Leipzig, 1922. (Sétima edição, Berlin: Duncker \& Humblot: 1996)

SCHMITT, Carl. Hamlet o Hecuba. La irrupcion del tiempo em el drama, trad. R. Pastor, Valencia: Universidad de Murcia, 1993.

SELIGMANN-SILVA, Márcio, "Catástrofe, história e memória em Walter Benjamin e Chris Marker: a escritura da memória", in: História, Memória, Literatura. O testemunho na era das catástrofes, org. por M. Seligmann-Silva, Campinas: Editora da UNICAMP, 2003. Pp. 391-417.

SELIGMANN-SILVA, Márcio, "Após o 'Violento Abalo'. Notas sobre a Arte - relendo Walter Benjamin", in: O local da diferença. Ensaios sobre memória, arte, literatura e tradução, São Paulo: Editora 34, 2005. Pp. 19-30.

TAUBES, Jacob, Ad Carl Schmitt. Gegenstrebige Fügung, Berlin: Merve, 1987.

WEBER, Samuel, "Taking Exception to Decision: Walter Benjamin and Carl Schmitt", in: Diacritics, vol. 22, no. 3/4, Fall-Winter 1992, pp. 5-18. 
${ }^{1}$ Uma primeira versão este ensaio foi publicada em outra travessia. Revista de Literatura, n. 5, $2^{\circ}$. Semestre de 2005. Curso de Pós-Graduação em Literatura. Centro de Comunicação e Expressão. UFSC, pp.: 25-38.

${ }^{3}$ Nas citações do ensaio de Benjamin de 1921 remeto primeiro ao número das páginas da edição brasileira e em seguida ao número correspondente da edição alemã da Suhrkamp. Cf. bibliografia.

${ }^{4}$ Neste sentido, lembrando que Benjamin escreve após a Primeira Guerra Mundial, é importante confrontar este texto com o também famoso ensaio de Karl Jaspers sobre o problema da culpa (Die Schuldfrage) na Alemanha do pós-guerra, que ele escreveu em 1945-46. Ai o autor tenta refletir sobre a construção de uma nova ordem jurídica a partir da situação da derrota (e dos complexos sentimentos nos alemães, derivados desta derrota).

${ }^{5}$ Com relação ao triplo significado do conceito de catástrofe na obra de Walter Benjamin - que ora indica uma catástrofe contínua, ora uma catástrofe destruidora, ora uma catástrofe ao mesmo tempo aniquiladora e redentora - cf. o meu artigo de 2003.

${ }^{6}$ Neste sentido é importante recordar um fragmento deste mesmo período do espólio de Benjamin, onde lemos: "[...] a exigência de total ausência de Gewalt não pode ser determinada de modo exato (onde acaba a Gewalt?), não apenas [é] absurda na sua conseqüência, que nega a vida e até o suicídio, mas sobretudo não se pode fundamentá-la.” (GS VII, p.791)

${ }^{7}$ Chega a ser caricata a interpretação do conceito de waltende Gewalt como uma alusão a Walter do nome de Benjamin. (1994: 74-77)

${ }^{8}$ Benjamin 1996: 327. Cf. também uma menção rápida ao estudo da teoria da soberania no século XVII em uma carta a Gottfried Salomon-Delatour (Benjamin 1996: 400).

${ }^{9}$ Segundo Jacob Taubes esta carta "É uma mina que simplesmente faz explodir as nossas idéias sobre a história cultural da era de Weimar. A carta provém não dos inícios da época de Weimar, mas da época de sua crise: dezembro 1930.” (Taubes 1987: 27)

${ }^{10}$ Nietzsche, na sua Genealogia da Moral, também pensou a soberania como um conceito-limite. Para ele o todo poderoso (Mächtigsten) é o único capaz de decretar o perdão. (Nietzsche 1988: 309) Neste ato altruísta ele exerce e impõe seu poder, salvando a vida matável. Este fato aponta para o ser-excepcional do Estado de Direito, ou seja, para a verdade de que o Estado de Exceção habita o interior do estado de Direito e não lhe é estranho. Mais adiante na mesma obra Nietzsche formula: "É preciso mesmo admitir algo ainda mais grave: que, do mais alto ponto de vista biológico, os estados de direito não podem senão ser estados de exceção [Ausnahme-Zustände], enquanto restrições parciais da vontade de vida que visa o poder, a cujos fins gerais se subordinam enquanto meios particulares: a saber, como meios para criar maiores unidades de poder." (Nietzsche 1998: 65, correspondendo a Nietzsche 1988: 312 s.) Novamente encontramos aqui explicitada a lógica do direito natural que justifica os meios em função do poder e de sua unidade.

${ }^{11} \mathrm{Na}$ edição da Suhrkamp consta "Es gibt keine barocke Eschatologie" ("Não existe uma escatologia barroca", GS I, p.246), mas Agamben constatou no manuscrito (ou na primeira edição) que em Benjamin constava "Es gibt eine barocke Eschatologie", ou seja, "Existe uma escatologia barroca". Mas ele mesmo nota que a "correção" realizada pelos editores não violenta o sentido do pensamento benjaminiano, já que esta escatologia está de fato esvaziada: permanece o fim, mas acaba a sua transcendência e a possibilidade de redenção. Cf. Agamben 2005: 88s.

12 "Para a filosofia da arte", escreve Benjamin, "só os extremos são necessários, o processo historio é virtual. Por seu lado, o extremo de uma forma ou de um gênero é a idéia, que, enquanto tal, não entra na história literária. $O$ drama trágico como conceito poderia inserir-se sem problemas nas classificações conceituais da estética. Ma a idéia relaciona-se de modo diferente com as classificações, na medida em que não determina uma classe e não contém em si aquela universalidade sobre a qual assenta, no sistema de classificações, cada um dos graus do conceito, a universalidade da média estatística." (2004: 24s.; correspondendo a GS I, p.218. Tradução alterada.)

${ }^{13} \mathrm{Cf}$. ainda a tese de número quatorze: "A história é objeto de uma construção cujo local não é o tempo homogêneo e vazio, mas sim o preenchido pelo tempo de agora [Jetztzeit]." (GS I, p.701) Nesta mesma tese Benjamin faz uma reflexão sobre a moda como modo de citação do passado, que ela concilia com o faro para o atual. Neste sentido ela seria um "salto tigrino [Tigersprung] no passado". O problema é que a moda se dá sob a regência das classes dominantes. Seu movimento, no entanto, corresponde, na história, à citação, nas revoluções, de momentos anteriores. Para Benjamin, a revolução postulada por Marx promoveria um tal salto, Sprung, no "céu da história". Também a tese seguinte trata da ruptura. Ela introduz uma importante reflexão sobre o calendário e os dias de festa: temas privilegiados da teoria do Estado de Exceção. A tese se inicia com as palavras: "A consciência de arrebentar [aufzusprengen] o continuum da história é própria das classes revolucionárias no momento da sua ação. A Grande Revolução introduziu um novo calendário. O dia em que um calendário se inicia funciona como um acelerador histórico. E, no fundo, ele é o mesmo dia que sempre volta sob a figura dos feriados, que são dias de comemoração." (Id.)

${ }^{14}$ Taubes, comentando a oitava tese, escreveu: "Os vocábulos fundamentais de Carl Schmitt são introduzidos por Walter Benjamin, recebidos e revertidos no seu oposto." Mas em seguida ele introduz outra importante aproximação entre as esferas de pensamento destes dois autores: "O 'Tempo-de-agora' [Jetztzeit], uma monstruosa abreviação do tempo messiânico, determina tanto a experiência da história de Walter Benjamin como a de Carl Schmitt, ambas contêm uma concepção mística da história, cujo ensinamento essencial consiste na relação da ordem sacra com a ordem profana." (1987: 
